\title{
Education and training in heritage practices - the case of heritage craft education at University of Gothenburg as an opportunity for Albania
}

\author{
Bosse Lagerqvist \\ Department of Conservation, University of Gothenburg, Sweden \\ e-mail: bosse.lagerqvist@conseravtion.gu.se
}

\begin{abstract}
The intention of this article is to discuss the challenges in organising higher education in heritage practices and craft skills. The development of the Department of Conservation, University of Gothenburg, its establishment of a Craft laboratory, and the certification of craft skills in an Albanian context, is used as a case. Based on the activities of the Craft Laboratory in Sweden, the paper investigates the possibilities for a similar development in Albania. The background for the specific subject rests in long-standing cooperation between the Department of Conservation and Cultural Heritage without Borders Albania (CHwBA), in terms of skills development for improving restoration practices. Through the paper, it is clear that the same kind of context is not in place in Albania, and that the needs are different. It is also obvious that CHwBA is functioning as a de facto Craft Laboratory in Albania and the need for an outfit like that are more focused on improving competences, standards and qualities in the architectural restoration area, leading to economic development, employability, establishment of small craft companies, and formal branch networks. The article discusses the challenges facing the higher education systems in developing education as well as vocational training in the subject areas of heritage practices and craft skills.
\end{abstract}

Keywords - building crafts, heritage studies, craft training and education, craft science, heritage practices

\section{INTRODUCTION}

This article summarises the author's observations made during a recent sabbatical visit to Albania ${ }^{1}$. The visit was organised through cooperation between the Department of Conservation, the University of Gothenburg (UGOT-C), and the Albanian partners Cultural Heritage without Borders Albania (CHwBA), and the Department of Archaeology and Heritage Studies, University of Tirana. The author had previously for a number of years been involved in craftoriented restoration camps organised by $\mathrm{CHwBA}$ as a lecturer, and also as an external adviser in CHwBA's formulation of a Vocational Education and Training (VET) program in alignment with regulatory development in Albania in regards to restoration of historical buildings.

${ }^{1}$ A preliminary account of this work has been published in Lagerqvist (2019)
The author also experiences form a period as Head of Department of Conservation, which includes being responsible for the Craft Laboratory ${ }^{2}$ set up in 2010 as a resource for developing the area of craft science and models for craft practice, in cooperation with national bodies with different responsibilities related to historical buildings, gardens, parks and landscapes. In the pre-establishing phase of the Craft Laboratory, the author interviewed the county administrative boards throughout Sweden on their experiences from distributing governmental funds for restoration interventions that would imply the need for apply craft skills, and if they were able to validate the quality outcome of such interventions. (Lagerqvist, 2011) The result clearly indicated the need for improving the procurement

\footnotetext{
${ }^{2}$ https://www.gu.se/hantverkslaboratoriet/
} 
competencies within public administration, as well as the need for increased craft skills in certain areas.

Drawing on experiences from how UGOT-C has developed from 1978 including the establishment and activities of the Craft Laboratory, and how the development of Vocational Education and Training in heritage crafts in Albania could motivate a similar laboratory set up in order to bring together practitioners, academics, civil society, formal institutions, education providers, etc., this article intends to discuss the challenges in organising higher education in heritage practices and craft skills.

\section{HERITAGE PRACTICES AND CRAFT AS AN ACADEMIC SUBJECT}

In 1978 the bachelor's program in Integrated Conservation of Built Environments was set up at the University of Gothenburg. The program was a response to a number of observed dysfunctions in regards to understanding and managing the existing built environment as a resource for on-going and future societal development. The European Architectural Heritage Year in 1975, ended with a conference in Amsterdam where the final declaration stated that (ICOMOS, Declaration of Amsterdam):

The conservation of the architectural heritage should become an integral part of urban and regional planning, instead of being treated as a secondary consideration or one requiring action here and there as has so often been the case in the recent past./.../ There is a fundamental need for a better training program to produce qualified personnel. These programs should be flexible, multi-disciplinary and should include courses where on-site practical experience can be gained.

This internationally established understanding was one of the main inspirations for the 1978 program establishment in Gothenburg, another driving force was the transformation of urban and city centres that took place in Sweden during the 1960s and 70s. At the University of Gothenburg, a report was released at that time stating that the possibilities for students with a degree in either art history, ethnology, or archaeology, to become professionals within heritage practices were limited, although their subject was immensely important to balance economical, technical, or other competence areas involved in the transformation of buildings and urban areas (Engelbrektsson et al., 1976). In the years following 1978, the program became a firmly positioned education resource in the Swedish heritage area. The ability within the program to combine knowledge of the subject matter, i.e. the history of built environments and how this subject matter is valued and interpreted differently in the contemporary society, but also historically, together with training on how to operate this within a number of societal processes while at the same time, through a critical perspective, discuss and develop such processes (Lagerqvist, et al., 2014). In 1985 the bachelor's program in Conservation of Cultural Objects was established followed by the introduction of the PhD-program in 1992, and in 2005 the higher vocational education courses in heritage crafts within traditional building technologies, historical garden and park, and cultural landscapes, organised in Mariestad, were incorporated in UGOT-C as bachelor's programs. Finally, the last components added to UGOT-C, thereby strengthening its broad perspective on material culture and its intangible qualities and how to use these as assets in societal development, was the master's program in Conservation in 2008, the bachelor's program in Leadership in Handicraft in 2011, and the master's program in Conservation of Cultural Heritage Objects in 2019. All these educational initiatives share what Peter Sjömar describes as the concept of this scientific area, as being theoretical in the sense of explaining and understanding heritage procedures and processes, but also being practical since the exploratory methodologies and surveys include the ability to execute procedures and control the processes (Sjömar, 2013).

With the incorporation of the Mariestad facilities, a starting point became possible for developing a full academic structure in heritage crafts within the subject area conservation. This implied also $\mathrm{PhD}$-education and research projects, and to date a number of doctoral dissertations have been presented within areas such as timber framing (Hjort Lassen, 2014), plant propagation (Westerlund, 2017), traditional lime mortar (Eriksson, 2019), to name a few.

However, craft has not always been regarded as an area of qualified competences. The Swedish master engineer Christopher Polhem wrote in 1710 (citation from Almevik, 2004, who refers to Polhem, 1710):

The method craftsmen use to learn the young serves only the stupid ones who like slaves through long practical training rather than intellectual capacity makes them skilled to produce things in a certain manner without reflection on improvements. But for smarter people less interested in a life in slavery, beautiful books and descriptions provide a better fundament... (translated by author).

This image of craft is still very vivid for most people and it is not unusual that it is referred to as the "knowledge of the hands' - as if there were no need for actually understanding how and why a certain product should be manufactured through a certain process.

Establishing craft as an area for qualified education and research might therefore be a challenge based on the (mis)understanding of 'knowledge' following the principles of a theoretical knowledge tradition. The SwedishNorwegian philosopher of ideas, Bengt Molander, discusses the differences between theoretical and practical knowledge traditions through a number of comparable perspectives. (Molander, 1996) In the theoretical tradition the relation between subject and object becomes an obvious dualism where knowledge is understood as knowledge about something that is separated from the subject, whereas in the practical tradition this dualism is rejected and instead the knowledge is rooted in living traditions living with materials, tools, etc. In the theoretical tradition knowledge do not need to be applied and if applied it is regarded as a separate moment, the practical tradition on the other hand stresses the unity between knowledge and application based 
on the understanding of knowledge as knowledge-in-action. Knowledge as a provider of images of reality and that knowledge can be formulated and expressed through words and numbers, is fundamental for the theoretical tradition. In the practical tradition, knowledge is instead regarded as necessary for guiding processes that lead from questions to answers and from tasks to completion, and in this respect, knowledge is basically tacit but could also be expressed through words and numbers.

So, according to Molander, knowledge within craft refers basically to applied knowledge or knowledge in action. This does not mean there is no need for theory. Theory is fundamental for understanding the practical knowledge tradition and also for our ability to research and educate in the craft. It is therefore necessary to look closer at the concept of theory. In the Oxford English Dictionary, (Oxford English Dictionary, 2020) 'theory' is defined:

1. a. The conceptual basis of a subject or area of study. Contrasted with practice.

/.../

3. A conception of something to be done, or of the method of doing it; a systematic statement of rules or principles to be followed.

/.../

4. Mental view, insight; contemplation

/.../

6. a. An explanation of a phenomenon arrived at through examination and contemplation of the relevant facts; a statement of one or more laws or principles which are generally held as describing an essential property of something.

b. More generally: a hypothesis or set of ideas about something (underlining by author).

From this, it is possible to state that this might be understood as the theory of 'doing'. If we on the other hand look at how 'practice' is defined, we might understand this as the practice of 'doing' (Oxford English Dictionary, 2020):

1. The carrying out or exercise of a profession,

2. a. The actual application or use of an idea, belief, or method, as opposed to the theory or principles of it; performance, execution, achievement; working, operation; (Philosophy) activity or action considered as being the realization of or in contrast to theory

l.../

c. The action of doing something; method of action or working

l.../

4. Repeated exercise in or performance of an activity so as to acquire, improve, or maintain proficiency in it; activity undertaken to this end; (also) the familiarity with or proficiency in a subject or activity so acquired (underlining by author).

One of the challenges in higher education oriented towards heritage practices and craft skills is to combine the theory and practice of 'doing'. The dualism of theory and practice, of thinking and doing, is constantly present in the general understanding of curricula design for VET, but as Hyland points out, the conceptions of how intellectual, ethical and manual activities are linked, might provide insights in renewed debates on this issue (Hyland, 2017). There is, of course, a relation between practice and theory, in some areas the level of theoretical understanding combined with practical skills is not questioned, for example in heart surgery or setting up complex chemical laboratory experiments. This is the case, argued for here, also for heritage crafts, which are needed in order to effectively, sustainably and with high-quality secure preservation, maintenance and development options of the built environment and the cultural landscapes. As with design or architecture, knowledge development in craft is governed by 'practice-led research', which in short means that practice is seen as the natural arena for inquiry and the methods of practice are applied as methods of inquiry (Rust, et al, 2007). Following Sjömar's understanding of the concept of heritage, or craft, science as being able to understand, explain and execute processes and procedures, implies that the practical execution can be the investigative methods, resulting in a dialectical, or hermeneutical process of discovering, learning, rediscovering, and so on, as a learning-by-doing activity (Gill, 2018).

\section{BACKGROUND AND CONTEXTUAL FRAMING}

The Balkans has a long and complex history, not seldom with strains and sometimes resulting in open conflicts, such as the Yugoslav wars in the 1990s. (Finlan, 2004; Naimark, Case, 2003) In 1995 the Swedish NGO Cultural Heritage without Borders was established to use heritage as a conflict-breaker in the post-war western Balkans. The organisation has since then firmly settled in the region with offices in Albania (Tirana and Gjirokastra), in BosniaHerzegovina (Sarajevo), and in Kosovo (Prishtina). Since 2015 these offices have been turned into separate autonomous organisations within the frameworks of respective country's regulations. The links between UGOT$\mathrm{C}$, and the CHwB-offices of the western Balkan has developed since the first contact in 2010 , mostly centred on questions of building crafts and restorations.

Albania has been in the forefront of introducing requirements on craft skills in restoration projects and in cooperation with primarily Ministry of Economy and Finance, Ministry of Culture, Institute of Monuments of Culture, Regional Directorates of National Heritage, NAVETQ - National Agency of Vocational Education, Training and Qualifications, and Regional Directorates of Public Vocational Training, CHwB-Albania has developed a vocational training module for the certification of both senior and younger craftspeople, called 'Skills for Employability of Tomorrow'. In the future development of this model, a number of long-term needs and opportunities can be identified and where the concept of the Craft Laboratory represents a possible mean as well as a goal.

The notion of craft science as practice-led research implies routines for cooperation between the academia and the 
practice field, in this case, the heritage area. By tradition in the Swedish context, the government provides funds that should secure the preservation and maintenance of historic buildings, parks and landscapes, and those activities naturally are dependent on the quality of the applied crafts in the different projects.
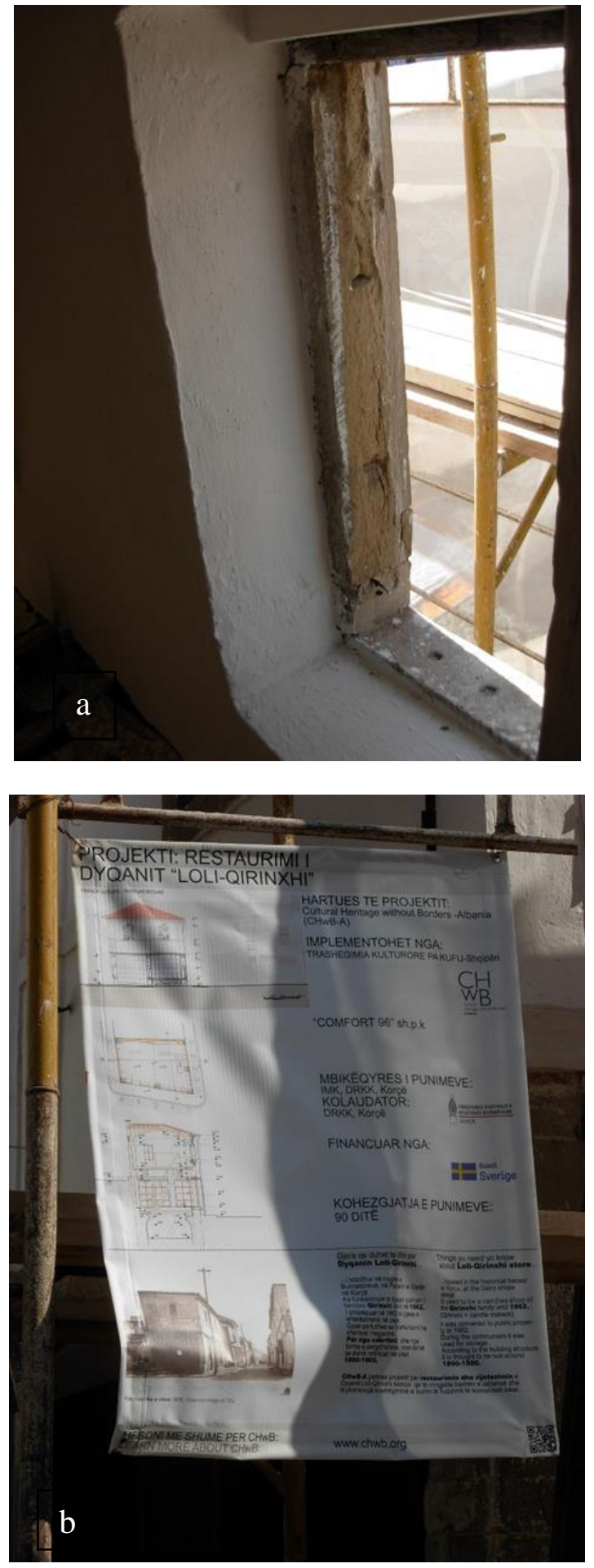

Figures $1 \mathrm{a}$ and $\mathrm{b}$. Restoration in progress by CHwBA, the bazaar area, Korca, Albania (photo: Bosse Lagerqvist)
A joint understanding among central national bodies in the heritage area to improve craft procedures and quality control provided the requirement for establishing the Craft Laboratory in 2010 in Mariestad as a unit within the Department of Conservation, UGOT. It was set up as a national centre for the heritage craft and a platform for craftspeople to document and develop knowledge in crafts. The aim was and still is to develop and support the advanced craftsmanship required to safeguard the culture-historically valuable environments for a sustainable future. It operates through collaboration between the academy and the public heritage administration, primarily the National Heritage Board, The National Property Board, the preservation officers at the County Administrative Boards, The National Swedish Handicraft Council, The Swedish Local Heritage Federation, and the Swedish Church.

The fundament for establishing a Craft Laboratory in Sweden was the need for improving the control of how governmental funds for restoring and maintaining heritage ought to result in acceptable quality outcomes. To an increasing degree, it was understood that the practical operation of restorations in terms of applied crafts and construction materials, did not always reflect high quality and long term sustainability. Since the early 1960s, there had been an on-going decrease of craft skills in general within the construction sector, favouring instead prefabrication and industrialisation of procedures within construction and building. The growing lack of qualified craft skills also naturally affected restorations and maintenance interventions of listed buildings as well as historic houses in general. Not only was the availability of qualified craftspeople a problem, in some crafts there was also a total lack of persons, but there was also a limping ability to competently procure craft quality in governmentally funded restorations as well as the evaluation of the standard of quality in performed interventions.

In Sweden, the government funds interventions on heritage with a total sum of 270 mil. SEK, or c. 25 mil. Euro, distributed to the County Administrative Boards through the National Heritage Board. For restoration and maintenance of the religious heritage, i.e. the Swedish Church, the government funds amount to 460 mil. SEK annually, or c.42 mil. Euro. (Kulturutskottets betänkande) In addition to these figures, public bodies like the National Property Board, The Fortification Administration, and the Swedish Transport Administration are investing in restoration and maintenance in properties with heritage values and that are owned by them. There is therefore a substantial interest from the public bodies on national and regional levels in the Swedish society to increase the quality and life span of restoration interventions, thus reducing the long-term property management costs. This of course was a sharp motivation for establishing the CL.

In Albania, the situation is somewhat different. The annual state budget directs just over 16 mil. Euro for culture and out of this 1,6 million Euro is for investments in cultural heritage (personal communication, CHwBA). This 
corresponds to roughly $0.07 \%$ of the annual state budget, whereas the 270 mil. SEK for similar investments in the Swedish context corresponds roughly to $0,0002 \%$ of the annual state budget. Even when including the 460 mil. SEK for the religious heritage the proportion in Sweden of the annual state budget for investments in cultural heritage does not reach the proportion the Albanian government issues for cultural heritage. However, taking the actual disposable funds into consideration, the situation in Albania is in a more inferior state. Restorations and cultural heritage activities, therefore, depend on international investments in order to be secured, and the important actors are (personal communication, $\mathrm{CHwBA}$ ):

- The American-Albanian Development Foundation, AADF, spending roughly 3 mil. Euro per year.

- The Turkish Cooperation and Coordination Agency, TIKA, invests c. 0.8 mil. Euro per year primarily in restorations of mosques.

- The Swedish International Development Cooperation Agency, SIDA, that through CHwBA invests c. 0.25 mil. Euro per year.

- The European Union invests c. 0.25 mil. Euro per year.

Apart from these organisations, The Deutsche Gesellschaft für Internationale Zusammenarbeit, GIZ, has since long been investing in a number of activities in Albania where heritage interests often are addressed to various degrees. So for example, the vocational training module for the certification of craftspeople, developed by $\mathrm{CHwBA}$, is to a large degree funded through GIZ by means coming from the German federal state of Hessen.

The same basis as in Sweden for motivating a Craft Laboratory does not exist in Albania, in terms of internal public stakeholders, governmental funds, and an established academic structure for higher education and research in heritage crafts. Instead, there are other needs that must be met and that precede the organisation of a Craft Laboratory.

Restoration of listed buildings in Albania is designed and executed by licensed conservation/architectural companies, and the licensing system is governed by The Institute of Cultural Monuments "Gani Strazimiri", IMK. The grounds for being licensed as a company are based on having an employee that is a licensed restoration architect. The formal requirements for being licensed are a) having a professional master's degree in relevant subjects, i.e. architecture, urban planning, construction engineering, and b) having at least 7 years of work experience including a certain number of restoration projects depending on what level of certification is applied for (IMK, Kartelat e Licensimit). The license has a lifelong validity. Presently there are 22 companies that in this way are licensed for both designing and executing restorations, and there are another 8 companies that are licensed only for executing restorations as well as 1 company licensed for only designing restorations. (IMK, Lista me subjektet) When it comes to craft the construction workforce is not specifically trained for working with historic buildings and traditional skills, but through the program developed by $\mathrm{CHwBA}$, an increasing number of construction workers becomes certified as an assistant craftsman and master craftsman. ${ }^{3}$ The normal training procedure in Albania for developing craft skills is through on-the-job learning processes, and there is a historical background for this. In 1962 a number of conservation ateliers were established with responsibilities to run maintenance and restoration works on monuments. These specialised institutions attracted skilled craftspeople and were soon developed into de facto apprentice based schools securing the continuation of craft skills. With the fall of the previous regime in the early 1990s this activity ended, although a number of master craftspeople from that period are still active, and through the CHwBA program, they are today formally getting recognised as certified masters in craft (Aquilar, et al., 2019, p. 2049).

The incentive for 'Skills for Employability of Tomorrow' is that restoration work on listed buildings should normally require certified craftspeople, but it has not been unusual that the licensed restoration company to date has executed restorations also with non-certified craftspeople. There is presently a process taking place through negotiations with the Ministry of Culture to enabling the licensing of master craftspeople thus providing them with the authorization to set up their own companies for smaller restoration projects. Apart from the possible outcome of this process, there are changes underway in the bylaws of the relatively new law on Cultural Heritage and Museums requiring licensed companies to get their employed craftspeople certified following the vocational training module for the certification of craftspeople.

The certification of the expert on cultural values follows the normal structure for construction works according to the Planning and Building Act, implying the set-up of a control plan incorporating not only cultural values but also certified experts on fire, energy, functionalities, and accessibility. The certification is valid for 5 years and is evaluated every year in terms sufficient number of assignments and the resulting outcomes. In order to be duly qualified for certification (of cultural values) the person need to fulfil education requirements of at least a bachelor's degree comprising knowledge in history of built environments, architectural history, and theory and history of conservation, relevant professional experience amounting to a minimum of three years full-time work, and finally, a letter of reference (from a formal heritage body) certifying the eligibility of the candidate. Before certification is provided the candidate needs to succeed in an exam on the legislative framework for restorations focusing primarily on the Planning and Building Act and Ordinance, the Heritage Act and Ordinance, relevant parts of the Swedish Environmental

\footnotetext{
${ }^{3}$ To date 115 has been certified as assistant craftspeople and 16 as master craftspeople. $C H w B$ Albania, Annual report 2018 .
} 
Code, and Boverket Building Regulations. (Boverket, Sakkunig kontrollant; Boverket 2012). Today there are around 165 persons certified as experts on cultural values (Boverket, Certifierade sakkunniga).

Students in vocational educations on the secondary level (Swedish gymnasium) could after the education voluntarily be tested for journeyman's certificate, and after sufficient work experience also test for a master craftsman's certificate. These possibilities are formulated by concerned trade organizations, equals the concept of 'chambers', and decided by the Swedish Craft Council (Sveriges Hantverksråd).

\section{WHO ARE THE STAKEHOLDERS IN ALBANIA?}

Within the concept area of this paper comprising historic buildings, restoration interventions, skills and expertise, training and education, and research, the concerned stakeholders could be principally sorted into different groups:

A. Public bodies

B. Commercial entities in architecture, construction and materials production

C. Specialised craftspeople, conservators, and heritage professionals

D. Foreign and domestic investors and donors

E. Training and education

\section{A. Public bodies}

The Ministry of Culture has the political responsibility to organise and fund activities that, amongst other tasks, aim at securing heritage, and further to oversee the compliance to the legislative framework regulating the heritage practice field. The Institute of Cultural Monuments "Gani Strazimiri", IMK, is established as a governmental agency under the Ministry of Culture, with the objectives to protect, preserve, restore and revitalize cultural heritage. The National Council for Restoration, a body of experts headed by the Minister of Culture and having a director of IMK acting as a secretary is operative responsible for licensing restoration architects and all others falling into categories of restoration licensing, i.e. restorers of works of art; companies; etc. In the organizational structure of IMK six regional offices are established, Drejtoria Rajonale $e$ Kulturës Kombëtare, DRKK (Ministria e Kulturës). The regional offices have close contact with applying the national policy for preserving the heritage, supervising and controlling the operations of restoration and maintenance interventions.

\section{B. Commercial entities in architecture, construction and materials production}

Presently there are 22 conservation companies that are licensed for both designing and executing restoration projects, and there are 8 companies that are licensed for executing interventions. There is also one conservation studio that is licensed for designing restoration projects (IMK, Lista me subjektet).
Apart from these companies, there are huge numbers of architectural companies that are not licensed for working with listed historic buildings, but with an increasing market for adapting and restoring historic houses - although not formally listed - one could expect an increased interest for becoming a licensed unit, or rather one could hope for increased interest. Within this group, it is also relevant to sort all the companies that are commercially active in producing and distributing construction materials for restoration projects.

In total, this group is strategically important to reach out to, but what is presently lacking is a professional network for these companies that operate in the heritage field. As a comparison Sweden has a number of such networks that organise issues of joint interest ${ }^{4}$, these networks could be accredited (SWEDAC) and thus create systems for formulating e.g. formal tests for the master craftsperson. In Albania, there is a rudiment for such a function in the National Chamber of Craft, although it has been hardly visible since its establishment in 2017 it has turned fully operational in December 2018. Its main task should be the responsibility for licensing and certification of craftspeople and for drafting the curriculum for relevant professions. The chamber will also include certified assistant craftspeople to be part of the official Registry of the Chamber of Crafts and thus improving the professional exposure and employment opportunities.

\section{Specialised craftspeople, conservators, and heritage professionals}

In this group is also CHwBA since they are heritage professionals in an NGO, implying not a public body or a commercially based company. To some degree it is possible to state already now that they act as the Craft Laboratory in Mariestad:

- they initiate cooperation between public bodies to improve restoration outcomes,

- through the restoration camps they promote the understanding of the complexity of advanced craft skills,

- they actively promote the need for integration of academic theory and methods with the understanding and dexterity of crafts kills to improve heritage outcomes,

- through the vocational training module for the certification of craftspeople, they strive for improving the quality of craft skills for restoration.

In the future, this group will also contain self-employed master craftspeople, and possibly conservators and heritage professionals running small consultancy companies.

4 Examples: Practising and consulting heritage professionals, http://spba.se/; Companies in building preservation, http://byggnadsvardsforetagen.se/;

Companies in preservation and restoration, http://fibor.org/; Association for plaster and mason contractors, https://www.spef.org/ 


\section{Foreign and domestic investors and donors}

This group is composed of, as mentioned previously, AADF, TIKA, GIZ, SIDA, but also the Albanian Development Fund, ADF, established as a development agency in 1993. Their activities cover investments in the development of infrastructure, urbanization, tourism and cross-border cooperation, and with a certain focus on the tourism sector with the development of studies and intervention plans at the regional and national levels. It has its main office in Tirana and ten regional offices for each region of Albania.

\section{E. Training and education}

Although NAVETQ - National Agency of Vocational Education, Training and Qualifications, and the Regional Directorate of Public Vocational Training, are principally public bodies they are put into this group of stakeholders. The vocational training module for the certification of craftspeople, 'Skills for Employability of Tomorrow', has its system for certification provided by NAVETQ. During autumn 2018 the process for turning this training certificate into a national standard started by NAVETQ, and when this goal has been reached the regional VET centres can host and run this training.

The Albanian school system follows in principle the general layout in a European context, meaning that there are professionalizing education programs on secondary levels and these vocational educations could offer three levels. (National Strategy for Vocational Education) Level I is composed of two years of study preparing semi-skilled workers, Level II offers one-year providing skilled workers, and Level III is a further year preparing technical experts/managers and also makes the students eligible for higher education. According to a report from the Albanian government (Ibid., p. 28) there were five schools in Albania in 2011 offering vocational education in construction and where the specializations offered (Level II) were: a) Tile laying and wall dressing, b) Carpentry, iron shaping and cementing, c) Brick laying and plastering, and d) Roadworks, road repairing (Ibid., p. 28). At least the specializations a) to c) could be subject to, in the future, opportunities for students to combine exams with the certification tests for assistant craftspeople, following e.g. the Swedish model. In Sweden, the corresponding level to assistant craftsperson would be 'journeyman' (Det händer med händerna). Due to this the schools offering vocational education on the secondary level also need to be considered as stakeholders in a possible future Craft Laboratory. This is specifically interesting if also a Level III is linked to these specializations, which would enable those students to proceed with higher education, although there seem to be small possibilities to establish heritage craft skills as a university or polytechnic subject in the near future. For this reason, it would also be important to identify as possible stakeholders at least The Faculty of Architecture and Urbanism of Tirana Polytechnic University, and The Department of Archaeology and Heritage Studies the University of Tirana.
An academic perspective on craft skills also includes how to research and document local traditional craft varieties, not necessarily linked to building crafts but part of craft traditions. In this field the Academy of Albanological Studies, Akademia e Studimeve Albanologjike, through their Institute of Cultural Anthropology and Art Studies. The institute hosts three departments. Ethnology, Folklore, and Art Studies (Akademia e Studimeve Albanologjike).

\section{Conclusion on stakeholders}

Apart from grouping the stakeholders in different themes, they could be identified as more immediate respectively as more of a potential stakeholder, when it comes to taking further steps heading towards the creation of a Craft Laboratory in Albania. The more immediate would from this description be:

- The Ministry of Culture
- The Institute of Cultural Monuments "Gani
Strazimiri", IMK
- The National Chamber of Craft
- $\quad$ Cultural Heritage without Borders Albania
- National Agency of Vocational Education, Training
and Qualifications, NAVETQ including some of the
and Qualifications, NAVETQ including some of the regional vocational education centres.

For more long term development a number of potential stakeholders are:

- Faculty of Architecture and Urbanism

- Department of Archaeology and Heritage Studies

- Institute of Cultural Anthropology and Art Studies

- $\quad$ ADF, AADF, GIZ

- Possibly several commercial entities with some certified craftspeople and skilled restoration architects.

These institutions and organizations are stakeholders in issues relating to the quality standards of restorations, the quality of craft skills, the training and education of craftspeople, the research and knowledge development on and in craft, the development of models, methods and materials for restorations. Eventually, the result might be an Albanian Craft Laboratory, but as stated initially, there are a number of preceding steps needed to be taken.

\section{THE CONTINUED DEVELOPMENT}

The Albanian context for heritage craft differs substantially from the Swedish situation. A craft laboratory following the same model and motivation as in Sweden would not be possible - at least in this stage. It is also important to note the fact that in principle the NGO Cultural Heritage without Borders Albania, is acting as the Craft Laboratory model as stated above.

So, what are the different important development steps needed to be taken in order to improve the quality of restoration and to promote craft skills as not only a heritage economy but in the long run also a strategic societal resource for circular economy and sustainable resilience? A group of national experts within a number of EU member countries have through the Open Method of Coordination 
within the framework of the European Work Plan for Culture, investigated the situation for traditional skills. (Galán-Pérez, et al., 2019) In a relatively early stage, the group concludes amongst other issues, that "The member states should implement national qualification frameworks for cultural heritage professional skills". (Ibid., p. 66) They further note that "A European lifelong learning guidance toolkit should be explored as a mechanism for cultural heritage professions to co-ordinate the organization of /.../ formal training and self-development". (Ibid., p. 66) In regards to these two perspectives, it is obvious that Albania already has taken important steps. It is though, possible to identify a number of items or actions to further develop or to put into implementation:

\section{On short term}

- Long term securing of the 6 months vocational training module for the certification of craftspeople. This implies that NAVETQ takes full responsibility for the training module to be operated by some of the regional vocational training centres. Before that is possible the regional vocation training centres need to be subjects for an inquiry aiming to identify the centres best suited for running the module, i.e. what is in place and what is needed to be operational.

- Securing the funding of the process as well as objects for restoration where also synergetic effects could be reached with continued funding of the Regional Restoration Camps. (Camps Guide) This implies meetings with the major donors and funders so far of $\mathrm{CHwBA}$ activities $\mathrm{ADF}, \mathrm{AADF}, \mathrm{SIDA}$, and GIZ, to reach agreements on continued funding.

- Promoting the establishment of functioning network activities between commercial restoration/conservation architectural companies, through a functioning National Chamber of Craft. This implies meeting with the chamber in order to understand what kind of supporting actions might be needed to initiate concrete activities.

\section{On medium term}

- Licensing of craft masters to increase selfemployment through the establishment of small craft companies. The IMK is governing the licensing system and a functioning National Chamber of Crafts would most probably be needed to enforce a development in this direction. Possibly there might be interest from some of the foreign donors to support such steps since it would promote an increased establishment of small companies within heritage craft, which might also have an effect on the development of local economies.

\section{On long term}

- Develop the vocational training into a two-year vocational education on heritage crafts. On which level in the education system this potentiality would be positioned is not absolutely clear. It could be designed as the Levels II and III of the secondary level vocational schools, it could be positioned within the existing VET-structure, or it might also, on a yet longer perspective, be the starting point for university-based educations in heritage crafts. The motivation for a two-year vocational education, would be that the 'restoration sector' or the more primary stakeholders as described previously, clearly could formulate the need for better-qualified professionals in heritage craft.

- Develop academic research on craft procedures and construction materials for restorations, to improve long term performance qualities, improve opportunities for small commercial entities to be established, and to provide didactic resources for training and education. The Faculty of Architecture and Urbanism, FAU, at the Polytechnic of Tirana, has started a professional master's program in the restoration of cultural monuments, (Master Profesional në Restaurim Monumentesh Kulture) and following the normal logics of academic life, research supporting this master is a foreseeable development.

- Improvement of the existing licensing system to improve and expand the level of knowledge and competence required for restoration projects. This possibility is relying on the parallel development of educational levels, which in turn would be the outcome of the principal stakeholders' interest and motivation for pursuing an argumentation for improving heritage craft skills.

\section{EduCATIONAL CHALLENGES}

The long-term development goals in Albania, as formulated above, will have to interact with the challenges facing higher education within the realms of heritage practices and craft skills. One challenge concerns how the activities of the practice are defined. At UGOT-C education, research and interaction with the surrounding society have been based on an understanding framed by the concept 'integrated conservation'. It stems from the Declaration of Amsterdam in 1975, and the referencing to integrated conservation made by Donal Appleyard in his introduction to Conservation of European Cities, where he discusses the need for being able to work both with physical conservation but also with 'social conservation' meaning the maintenance in a neighbourhood of the existing population (Appleyard, 1979, $\mathrm{p}$ 33). Following Appleyard and the Declaration of Amsterdam heritage practices by nature are performed within dynamic complex situations. Within the context of integrated conservation, Bernard Feilden defined 'conservation' as "the dynamic management of change in order to reduce the rate of decay" (Rosvall, Aleby, 1983, p. 23). The variety of causes of decay, Feilden groups into External causes, such as climatic effects, natural disasters and consequences of biological and botanical activities. He continues with Internal causes which is oriented around issues such as humidity, contaminated air, and neglect. And finally he identifies Man-made causes where we find wars, fashion, pollution, vandalism, theft, etc. (Feilden, 2003, p. 92). Following Feilden's definition the objective for conservation, or rather heritage practices, is in an everchanging context counteract all these causes of decay, which indeed is a challenging task.

Another challenge is related to the fact that cultural heritage is both a product - the defined object or phenomena valued 
as heritage - and a process - how the definition and valuation have been managed. Traditionally the process is based on national formal organisations that top-down defines a national heritage. This has been described by Laurajane Smith branding the processes as Authorized Heritage Discourse/AHD (Smith, 2006). During the recent decades, increased awareness has raised recognizing both contemporary as well as intangible phenomena as heritage, both from the AHD-organisations as from evolving complementary structures such as local societies, trade and business, and the civil society.

The principal critique of the AHD however, is that it does not sufficiently employ a critical understanding of how the best cases lead to the understanding of heritage as an instrument for change. However, the more normal outcome seems to be that since heritage is regarded as a postmodern construction the historical objects could either be space for artistic reinterpretations neglecting the scholarly/scientifically based heritage research and knowledge development, or an arena for political right-wing parties. Such groups bordering on extremism tend to favour traditional heritage, out-dated interpretations and misconceptions of history and heritage, as legitimizing the greatness of their nation and motivates the exclusion of unwanted groups. The severe problem in these cases is that such political interest tends to make historical objects societally infected, resulting in severe problems for heritage

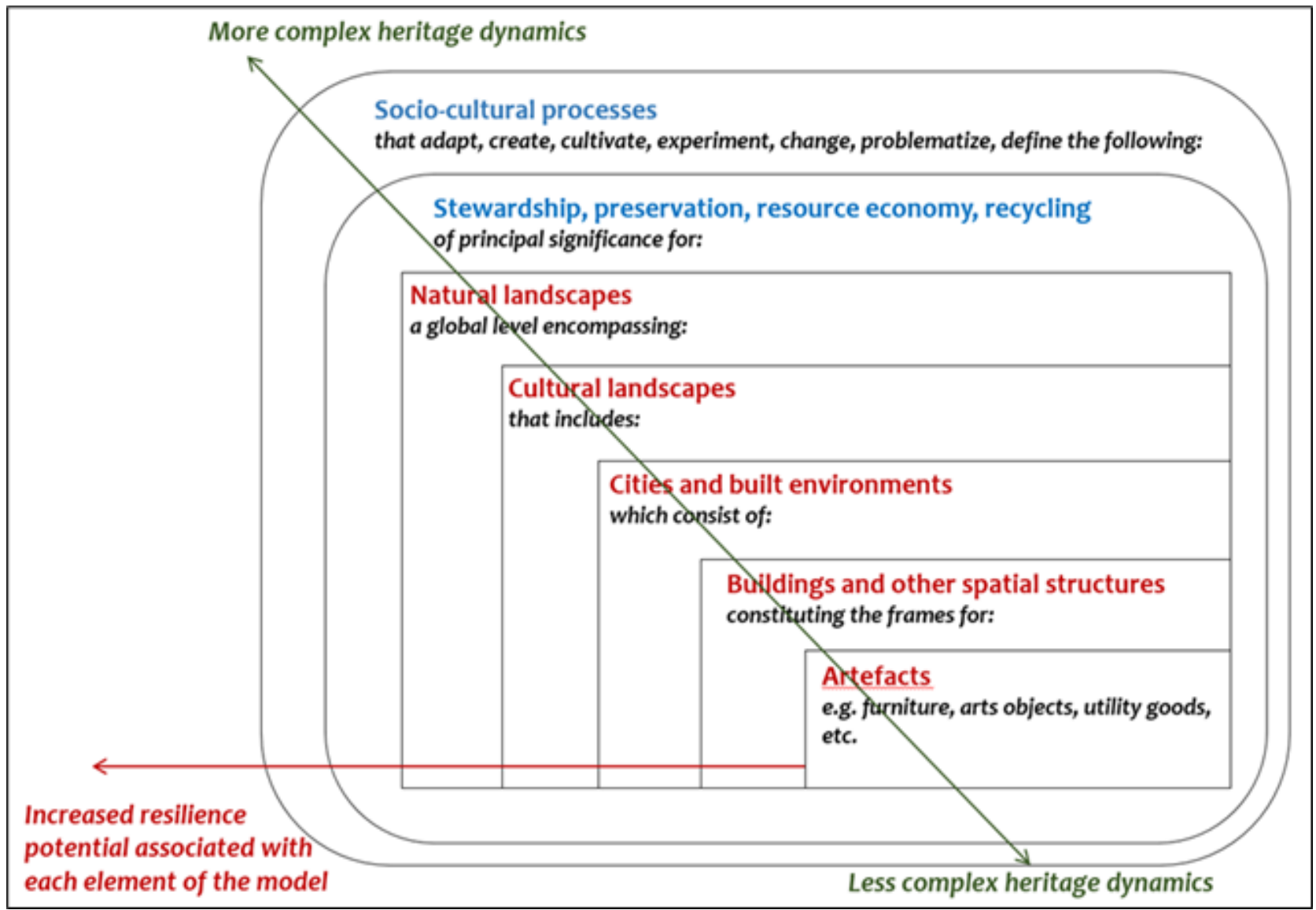

Figure 2. Heritage dynamics of the practice field (Lagerqvist, 2017)

history might be interpreted and narrated and that it does not take as its starting point the life of the ordinary people that seldom if ever, have been visible in the big historical pictures. This critique, to some degree, has also led to the understanding that the historical artifacts have no values or meanings per se, but rather that it is we that construct the heritage meaning within the conditions and limitations of present society. This implies then that a critique of heritage (AHD) is also a critique of society and by problematizing heritage through the perspective of the big societal challenges such as gender inequality, poverty, nationalistic movements, climate change, flows of refugees, etc., could in professionals, which also leads to critical perspectives on the critique of AHD (see for example González-Ruibal et al., 2018).

Following Ashworth (2011) development of paradigms can be identified indicating principles guiding heritage practices and how they change over time. He describes three different approaches, which, since the 1980s, coexist due to incomplete paradigm shifts. The preservation paradigm stems from the late $19^{\text {th }}$ century and represents a traditional perspective on the past and the objective is to protect specific objects from change, development or other threats. 
In the 1960s it was followed by the conservation paradigm where collections and environments were included together with specific objects and where contemporary use was addressed in relation to an imagined future. Finally, the heritage paradigm was emerging during the 1980s and is based on how cultural values are constructed in contemporary society and not something inherent in objects or environments. It also implies a shift from experts to how (ordinary) people use and value historic remains. A similar perspective is presented by Sully (2013) where he identifies three different approaches to conservation: Materials-based conservation which in principle represents a top-down expert-run practice focusing on material properties. The Value-based conservation approach is characterized by a dialogue between experts and stakeholders but still with a top-down decision-making process. Finally, he identifies the Peoples-based conservation approach based on bottom-up community lead activities where the welfare of the contemporary community takes precedence over tangible heritage.

The different paradigms of Ashworth and approaches according to Sully are often running in parallel in society but results in major differences in terms of types of heritage objects and their role and function in society, regulatory frameworks, recognition and valuation of intangible properties, costly expert-driven practices or participatory inclusive processes, and whether the operative interventions concerns traditional conservation as in consolidation, or restoration, or renovation, or reconstruction, or repair, or rehabilitation, or adaptive reuse. All concepts from a principle point of view naturally result in different processes and outcomes. From an education and training perspective, the students should be familiar with these different options and how the consequences affect how the practice is or should be performed.

\section{CONCLUDING REMARKS}

Higher education and training as well as VET, in the area of heritage practices and craft skills, are in reality a very challenging venture in the objective to enable the students to reach a general learning goal of understanding, explaining and executing. In difference with other study areas, this requires, from a very fundamental perspective, close interaction with the practice field, while at the same time maintain a critical, theoretical understanding of how, and why practice is performed and what possible alternatives could be formulated. Introducing a more holistic perspective of present sub-systems of the heritage practice area creates an even more complex reality of the heritage area. A complex reality is necessary to grasp if the objective of conservation/heritage practices is to decrease the rate of decay, following Feilden. The UGOT-C has experienced the benefit of creating the Craft Laboratory as an intermediate between academia and the practice field enabling valuable outcomes, both in terms of pedagogical resources to be used in education and training, but also creating a number of networks among practitioners representing joint areas of interest.
This paper was originated from a sabbatical in Tirana, where questions emerged whether Albania needed a craft laboratory, and how a possible laboratory would be organised. The layout of stakeholders in the Albanian context differ somewhat from the Swedish situation, which is also based on differences in the legal systems, differences in funding opportunities, and differences concerning the Vocational Education and Training system as well as the readiness within the higher education institutions to go indepth in heritage practices and craft skills.

The study confirms that the Cultural Heritage without Borders Albania is de facto acting as the Craft Laboratory of Mariestad, in terms of how they initiate cooperation between public bodies to improve restoration outcomes, and how they promote the understanding of the complexity of advanced craft skills. They further advocate the need for integration of academic theory and methods with the understanding and dexterity of crafts kills to improve heritage outcomes, and through the vocational training module for the certification of craftspeople, they strive for improving the quality of craft skills for restoration.

Although there is not the same public need for a craft laboratory in Albania as in Sweden, there is however a need for improving competences, standards and qualities in the architectural restoration area, but more focused on economic development, employability, the establishment of small craft companies, and formal branch networks. The future structural development would preferably contain stakeholder management, activities to bring up practical knowledge traditions to equal theoretical knowledge traditions, formulation of training schemes and program development within the formal education system, and development of formal licensing as well as entrepreneurial support structures to promote and improve economic development. The stakeholders consist of a group of central governmental bodies, the CHwBA, and some regional VET centres, this group could be complemented by university departments, international finding organisations, and commercial entities with certified craftspeople and skilled restoration architects.

\section{REFERENCES}

Akademia e Studimeve Albanologjike. http://asa.edu.al/site/ (Accessed on October 31, 2020)

Albanian Development Fund https://www.albaniandf.org (Accessed on October 31, 2020)

Almevik, G. (2004) "Förståelsen av hantverk som kunskap" In: Vem väver kejsarens nya kläder? Editors Anna Winbladh and Cecilia Bengtsson. Stockholms Hantverksförening.

https://www.yumpu.com/sv/document/view/20399483/vemvaver-kejsarens-nya-klader (Accessed on October 31, 2020)

Appleyard, D. (1979) "Introduction". In: The Conservation of European Cities. Editor Donald Appleyard. Cambridge, Massachusetts: The MIT Press, pp 2-49 
Aquilar, R., Torrealva, D., Moreira, S., Pando, M. A., Ramos, L, F. (eds.) (2019) Structural Analysis of Historical Construction. Springer International Publishing.

DOI: $10.1007 / 978-3-319-99441-3$

Ashworth, G. (2011). "Preservation, Conservation and Heritage: Approaches to the Past in the Present through the Built Environment”. In: Asian Anthropology, 10(1), 1-18. DOI: $\underline{10.1080 / 1683478 X .2011 .10552601}$

Boverket. Certifierade sakkunniga kontrollanter av kulturvärden. Boverket. [List of certified experts on cultural values. The Swedish National Board of Housing, Building and Planning]

https://www.boverket.se/sv/om-boverket/tjanster/hittacertifierade/ (Accessed on October 31, 2020)

Boverket. Sakkunnig kontrollant avkulturvärden. Boverket. [Regulation on Certified expert on cultural values. The Swedish National Board of Housing, Building and Planning]

https://rinfo.boverket.se/KUL/PDF/BFS2011-15KUL2.pdf

(Accessed on October 31, 2020)

Boverket (2012). Allmänna råd om ändring av byggnad, $B \ddot{A R}$. [General advice on adaption of buildings]

https://www.boverket.se/sv/om-boverket/publicerat-avboverket/publikationer/2006/allmanna-rad-om-andring-avbyggnad-bar (Accessed on October 31, 2020)

Camps Guide. Regional Restoration camps. Cultural Heritage without Borders Albania.

http://chwb.org/albania/wp-

content/uploads/sites/4/2018/04/Camp-booklet-

2018 lowres.pdf (Accessed on October 31, 2020)

Det händer med händerna. Sveriges Hantverksråd. [It happens with the hands, The Swedish Crafts Council]

http://hantverksrad.se/wp-

content/uploads/2014/12/Det_hander_med_hander.pdf

(Accessed on October 31, 2020)

Engelbrektsson, N, et al. (1976) A-E-K Arkeologi, Etnologi, Konstvetenskap. Göteborg: University of Gothenburg

Eriksson, J. (2019) Krympsprickor och historisk utveckling av material, metoder och förhållningssätt. Gothenburg Studies in Conservation 45. Göteborg: Acta Universitatis Gothoburgensis

Feilden, B. (2003) Conservation of Historic Buildings. Burlington: Elsevier

Finlan, A. (2004). The Collapse of Yugoslavia 1991-1999. Essential Histories. Oxford, England: Osprey.

Galán-Pérez, A., et al. (2019) "Fostering cooperation in the European Union on skills, training and knowledge transfer in cultural heritage professions" In: Professionalism in the
Built Heritage Sector. Van Balen \& Vandesande (eds.). London: Taylor \& Francis Group

Gill, K. (2018) 'Learning by doing: 'Working out' in craft research.” In: Craft Research, vol 9, No 1.

DOI: $10.1386 /$ crre.9.1.75_1

González-Ruibal, A. González, P.A., Criado-Boado, F. (2018) "Against reactionary populism: Towards a new public archaeology”. In: Antiquity Vol 92 Issue 362 (2018) 507-515.

DOI: $\underline{10.15184 / \mathrm{aqy} .2017 .227}$

Hjort Lassen, U. (2014) The invisible tool of a timber framer. A survey of principles, situations and procedures for marking. Gothenburg studies in conservation 32. Göteborg: Acta Universitatis Gothoburgenis

Hyland, T (2017) “Craft Working and the 'Hard Problem' of Vocational Education and Training" In. Open Journal of Social Sciences, 5, 304-325.

DOI: $10.4236 /$ jss. 2017.59021

ICOMOS. The Declaration of Amsterdam - 1975.

https://www.icomos.org/en/and/169-the-declaration-ofamsterdam (Accessed on October 31, 2020)

Kulturutskottets betänkande 2018/19: KrU1, [The Swedish Parliaments Committee on Culture, report on budget. Approved by parliament 2018-12-18]

http://www.riksdagen.se/sv/dokument-

lagar/arende/betankande/utgiftsomrade-17-kultur-mediertrossamfund-och_H601KrU1 (Accessed on October 31, 2020)

Lagerqvist, B. (2019) A craft laboratory in Albania? Problems and opportunities

https://www.academia.edu/41702711/A_CRAFT_LABORA TORY_IN_ALBANIA_Problems_and_opportunities

(Accessed on October 31, 2020)

Lagerqvist, B. (2017) "Conservation or reconciliation? Industrial heritage practices at a turning point", in Heritage and peacebuilding. Heritage Matters. Eds. Diana Walters, Daniel Laven \& Peter Davies. Martlesham, UK: Boydell \& Brewer Ltd.

Lagerqvist, B. (2011) "Länsstyrelsernas erfarenheter av vårdinsatser och behov av hantverksutveckling" In: Eva Löfgren, editor. Hantverkslaboratorium. Mariestad; Hantverkslaboratoriet, Göteborgs universitet. [The County administrative boards' experiences from restoration interventions and needs of craft development]

Lagerqvist, B., Holmberg, I. M., Wetterberg, O. (2014) "Integrated Conservation of Built Environments: Swedish Reflections from Three Decades of program Development." In: Preservation Education. Sharing best Practices and finding Common ground. Edited by Berry L. Stiefel and 
Jeremy C. Wells. Hanover and London: University Press of New England, pp 114-130.

Master Profesional në Restaurim Monumentesh Kulture, Faculty of Architecture and Urbanism, Polytechnic University of Tirana

https://fau.edu.al/en/programet-e-studimit/master-

profesional/ (Accessed on October 31, 2020)

Ministria e Kulturës, Insitucionet në varësi

http://www.kultura.gov.al/insitucionet-ne-varesi// (Accessed on October 31, 2020)

Molander, B. (1996) Kunskap $i$ handling. Göteborg: Daidalos [Knowledge in action]

National Strategy for Vocational Education Training and Lifelong Learning (2013-2020). Final Draft. Ministry of Education and Science, Ministry of Labour, Social Affairs and Equal Opportunities. 2012.

https://www.etf.europa.eu/sites/default/files/m/2F2ABAD2

B5A1126EC1257B650030CA17_TRP\%202012\%20Albani

a_EN.pdf (Accessed on October 31, 2020)

Naimark, N., Case, H. M. (2003). Yugoslavia and Its Historians: Understanding the Balkan Wars of the 1990s. Stanford University Press.

Oxford English Dictionary (2020)

https://www.oed.com/, entries 'theory' and 'practice'.

(Accessed on October 31, 2020)

Polhem, Chritopher, (1710), Almän hushåldz bygnad
Rosvall, J \& Aleby, S., editors (1988) Air Pollution and Conservation. Safeguarding Our Architectural Heritage. Amsterdam: Elsevier Science Publishers B.V.

Rust, C., Mottram, J. and Till, J. (2007) Review of practiceled research in art, design \& architecture. UK, Arts and Humanities Research Council.

Sjömar, P. (2013) Hantverksvetenskap. Rapport från försök med hantverksinriktad forskarutbildning. Göteborg, Institutionen för kulturvård [Craft science. Report from test period on craft oriented $\mathrm{PhD}$ education]

Smith, L (2006) Uses of heritage. London: Routledge

Sully, D. (2013) "Materials, values, and People in Heritage Conservation." In: Volume IV: Practice. Edited by Conal McCarthy. The International Handbook of Museum Studies. General editors Sharon MacDonald and Helen Rees Leathy. John Wiley \& Sons, Ltd.

Sveriges Hantverksråd

http://hantverksrad.se/ [The Swedish Crafts Council] (Accessed on October 31, 2020)

SWEDAC, a governmental body for accreditation. https://www.swedac.se/?.lang=en (Accessed on October 31, 2020)

Westerlund, T (2017): Trädgårdsmästarens förökningsmetoder. Dokumentation av hantverkskunskap. Gothenburg studies in conservation 41. Göteborg: Acta Universitatis Gothoburgenis 